\begin{tabular}{|lll|}
\hline Diterima & $:$ 15 November 2020 \\
Direvisi & $:$ & 10 Maret 2021 \\
Disetujui & $:$ & 30 Juni 2021 \\
Diterbitkan & $:$ & 30 Juni 2021 \\
\hline
\end{tabular}

\title{
CAGEUR BAGEUR BENER PINTER SINGER: FILOSOFI PENGASUHAN SUNDA DALAM PENDIDIKAN KARAKTER DI RAUDHATUL ATHFAL (RA)
}

\author{
Nuraly Masum Aprily ${ }^{1}$, Anggi Maulana $\mathbf{R}^{2} \&$ Purwati $^{3}$ \\ email: nuralymasumaprily@upi.edu¹, anggimaulanarizqi@upi.edu², \\ purwati_purwati@upi.edu³ \\ Program Studi Pendidikan Guru Pendidikan Anak Usia Dini, \\ Universitas Pendidikan Indonesia (UPI) Kampus Tasikmalaya \\ Jalan Dadaha Nomor 18, Tawang, 46115 Kota Tasikmalaya, Indonesia
}

\begin{abstract}
Abstrak: Raudhatul athfal (RA) merupakan lembaga pendidikan Islam yang memiliki sistem pengajaran dengan nilai-nilai ke-Islaman. Nilai-nilai ke-Islaman menjadi karakter bagi peserta didik dengan segala kekhasannya. Nilai-nilai dan budaya dari kearifan lokal suatu daerah tertentu menjadi sebagai salah satu landasan filosofisnya. Tujuan penelitian ini adalah mendeskripsikan landasan filosofis yang mendasari pelaksanaan pendidikan karakter dan bagaimana proses pelaksanaan pendidikan karakter di madrasah tersebut. Metode penelitian dengan studi kasus, dimana data dikumpulkan melalui observasi, wawancara, studi dokumentasi, dan studi literatur. Partisipan penelitian adalah seorang pemuka agama, seorang kepala sekolah dan dua orang guru. Teknik analisis data dengan cara reduksi data, penyajian data, penarikan kesimpulan dan verifikasi. Hasil penelitian ini adalah: 1) landasan filosofis pendidikan karakter di RA yang dituangkan dalam visi dan misi sekolah; 2) proses penyelenggaraan pendidikan karakter di RA melalui empat tahapan yang meliputi: pembiasaan shalat berjamaah, pembiasaan membaca lqro dan surat-surat pendek dalam al-qur'an, pembiasaan praktek ibadah, dan kegiatan-kegiatan ekstrakurikuler.
\end{abstract}

Kata-kata Kunci: akhlak, karakter, PAUD, Raudhatul Athfal

\section{CAGEUR BAGEUR BENER PINTER SINGER: PHILOSOPHY OF SUNDA CARING IN CHARACTER EDUCATION IN RAUDHATUL ATHFAL (RA)}

\begin{abstract}
Raudhatul athfal (RA) is a kind of kindergarten institution in Indonesia which teaching and learning system is based on Islamic values. In RA, Islamic values is instilled into good character for students with all their uniqueness. Even the values and culture of the local wisdom around the RA serve as one of its philosophical foundations. The purpose of this study is to describe the values and culture of local wisdom which is used as a philosophical foundation that underlies the implementation of character education and how the process of implementing character education in the school is. Data were collected through observation, interviews, documentation and literature study. Data analysis techniques by means of data reduction, data presentation, drawing conclusions and verification. The results of this study are: 1) the philosophical foundation of character education in RA Qurratu 'Aini is outlined in the vision and mission of the school; 2) the process of organizing character education in RA through four stages which include: habituation of congregational prayers, habituation of reading iqro and short letters of the Koran, habituation of worship practices, and extracurricular activities.
\end{abstract}




\section{PENDAHULUAN}

Pembentukan karakter harus dilakukan sejak dini untuk menanamkan nilai-nilai kebaikan kepada peserta didik, di mana sekolah tidak hanya menekankan pengembangan kognitif melalui hafalan tetapi juga mengembangkan afeksi berupa cinta kasih, pembiasaan, dan perbuatan yang baik dalam kehidupan keluarga, sekolah dan masyarakat (Pusat Perkembangan Kurikulum, 2009).

Pendidikan karakter adalah sebagai salah satu ikhtiar dan usaha pemerintah untuk memperbaiki kualitas karakter manusia Indonesia. Oleh karena itu, tentu perlu adanya perbaikan secara terus menerus dalam pelaksanaan pendidikan karakter di sekolah dan lembaga pendidikan.

Muhammad (2014) berpendapat bahwa penyebab pendidikan karakter di Indonesia belum berhasil, karena praktek pendidikan karakter di sekolah baru pada pembentukan sikap dan perilaku peserta didik. Menurutnya pendidikan karakter juga harus diperkuat melalui penanaman nilai-nilai keagamaan yang berbasis spiritual yaitu pendidikan agama. Sementara menurut Megawangi (2010) sebenarnya pelaksanaan pendidikan karakter di sekolah sekarang ini sudah diintegrasikan ke dalam berbagai mata pelajaran khususnya mata pelajaran PKn dan pendidikan Agama. Namun, pendidikan karakter dan pendidikan moral yang sebelumnya diajarkan melalui mata pelajaran Pendidikan Moral Pancasila (PMP), Pendidikan Pancasila dan Kewarganegaraan (PPKn), Pendidikan Kewarganegaraan (PKN) dan pelajaran agama dirasa belum berhasil membentuk karakter peserta didik karena meskipun subjeknya mengandung pelajaran yang baik, mereka tidak meninggalkan jejak dalam cara berperilaku peserta didik karena penanaman nilai-nilainya masih berfokus pada aspek kognitif berupa hafalan-hafalan saja (Izfanna \& Hisyam, 2012).

Berdasarkan kedua pendapat di atas, dapat disimpulkan bahwa sebenarnya penyebab belum berhasilnya pendidikan karakter di sekolah bukan karena kurangnya nilai-nilai karakter yang ditawarkan atau ditetapkan oleh pemerintah atau sekolah, akan tetapi proses menyampaikan dan mentransfer karakter itulah yang masih perlu diperbaiki dan ditingkatkan. Sebagai contoh metode pembelajarannya masih lemah karena terlalu fokus pada aspek kognitif level rendah seperti recall misalnya, namun belum merangsang aspek cognitive moral development di mana guru hanya mewajibkan peserta didik untuk mengetahui, menghafal konsep dan kebenaran tanpa menyentuh perasaan dan hati nurani yang merupakan orientasi dari cognitive moral development (Aprily, 2019a).

Pendidikan karakter memerlukan suatu strategi pedagogi dan metodologi yang tepat untuk menanamkan nilai-nilai kebaikan kepada diri peserta didik melalui pembelajaran di sekolah atau lembaga pendidikan lainnya (Cooley, 2008), karena ketidaktepatan metode yang digunakan menyebabkan pendidikan karakter menjadi tidak efektif. Kesalahan metodologis dan strategi pedagogis dalam praktik pendidikan karakter di sekolah akan berdampak panjang pada kehidupan moral siswa.

Kesalahan metodologis dan strategi pedagogis dalam praktik pendidikan karakter di sekolah yang dirangkum dari berbagai pendapat di atas dapat disimpulkan sebagai salah satu penyebabnya, dan hal ini akan berdampak panjang pada kehidupan moral siswa. Kegagalan pendidikan karakter (nilai agama dan moral) karena sekolah masih terbatas pada penyampaian moral knowing dan moral training tetapi tidak menyentuh moral being yaitu membiasakan anak untuk terus menerus melakukan perbuatan moral. Agar tercipta moral being siswa tentu dibutuhkan suasana kelas dan sekolah yang kondusif agar nilai moral tersebut teraplikasikan. Tugas seperti itu, menuntut sekolah untuk menjadi lembaga pembudayaan nilai moral, bukan hanya sebagai lembaga pengajaran moral dan lembaga pelatihan moral (Hakam, 2013). Pendidikan karakter bukanlah hanya slogan atau sekadar ilmu pengetahuan saja tetapi merupakan misi yang tertanam dalam kehidupan sekolah sehari-hari. Sekolah harus berfungsi sebagai tempat di mana siswa dapat mempraktekkan dan mengamalkan nilai-nilai kebaikan melalui pembiasaan-pembiasaan sehingga akhirnya terbentuk menjadi suatu budaya (Milliren \& Messer, M. H., 2009).

Lembaga pendidikan perlu segera merespon terhadap fenomena tersebut dengan cara semakin meningkatkan upaya dan perbaikan secara strategi dan metode dalam pelaksanaan implementasi pendidikan karakter di setiap tingkat satuan pendidikan, termasuk didalamnya pada tingkat Raudhatul Athfal (RA) sebagai bagian dari lembaga pendidikan Islam di Indonesia harus menjadi garda terdepan dalam pelaksanaan pendidikan karakter melalui penanaman nilai-nilai mulia yang bersumber dari ajaran Islam kepada peserta didik.

Secara filosofis karakter dalam pandangan filosof kontemporer seperti Michael Novak, adalah campuran atau perpaduan dari semua kebaikan yang 
berasal dari tradisi keagamaan, cerita, dan pendapat orang bijak, yang sampai kepada kita melalui sejarah. Menurut Novak, tak seorang pun yang memiliki semua kebajikan itu, karena setiap orang memiliki kelemahan-kelemahan. Seseorang dengan karakter terpuji merupakan suatu pembeda dari yang lainnya (Lickona, 1997). Sedangkan filsuf Yunani Aristoteles (dalam Lickona, 1997) mendefinisikan karakter yang baik adalah sebagai kehidupan seseorang yang benarbenar menjalankan perilaku dalam hubungannya dengan orang lain dan dalam hubungannya dengan diri sendiri secara baik.

Sementara itu Nucci (2017) mendefinisikan karakter sebagai kata dengan aplikasi yang luas dalam bahasa sehari-hari, dia menekankan bahwa karakter sebagai fenomena perkembangan seseorang yang “..not fixed by genes", melainkan sebagai hasil dari konteks dan pengalaman seseorang. Pernyataan tersebut mendukung pendapat Cronbach (1977) bahwa karakter bukanlah akumulasi dari kebiasaan dan gagasan yang terpisah. Karakter adalah aspek dari kepribadian, di mana keyakinan, perasaan, dan tindakan saling terkait, sehingga mengubah karakter seseorang sama dengan mengatur ulang kepribadiannya. Pelajaran kecil tentang prinsip-prinsip perilaku baik tidak akan efektif jika tidak terintegrasi dengan sistem kepercayaan orang tentang dirinya sendiri, tentang orang lain, dan tentang kebaikan masyarakat.

Dalam sudut pandang agama Islam, karakter yang baik telah dibahas dalam al-Qur'an dan Hadits dengan menggunakan istilah Akhlakul Karimah (perilaku mulia). Dalam bahasa Arab, bahwa kata akhlak adalah jamak dari kata "khuluq" yang berarti perangai, tabiat, dan sikap yang menetap kuat di dalam diri seseorang dan merupakan sumber dari timbulnya perbuatan-perbuatan tertentu dari dirinya. Hal ini sesuai dengan pendapat Miskawaih (dalam Aprily, 2019) yang menjelaskan akhlak adalah kemampuan jiwa untuk melahirkan satu perbuatan secara spontan tanpa pemikiran atau pemaksaan. Dilihat dari perspektif Islam, Maskawaih (dalam Hidayat, 2017) melanjutkan bahwa akhlak juga adalah ilmu pengetahuan tentang keutamaan-keutamaan dan cara memperolehnya agar jiwa seseorang menjadi bersih dan memiliki pengetahuan tentang kehinaankehinaannya jiwa, lalu kemudian bertekad untuk mensucikannya. Pentingnya karakter yang baik dalam diri manusia menjadi hal yang penting dalam Islam, oleh karena itulah Nabi Muhammad SAW diutus oleh Allah untuk menyempurnakan akhlak manusia, dan Nabi Muhammad SAW adalah sebagai Uswatun
Hasanah (teladan terbaik) yang harus dicontoh oleh seluruh manusia.

Berdasarkan pengertian di atas dapat dipahami bahwa karakter identik dengan akhlak, sehingga karakter merupakan nilai-nilai perilaku manusia yang universal yang meliputi seluruh aktivitas manusia, baik dalam rangka berhubungan dengan Tuhannya, dengan dirinya, dengan sesama manusia, maupun dengan lingkungannya, yang terwujud dalam pikiran, sikap, perasaan, perkataan, dan perbuatan berdasarkan norma-norma agama, hukum, tata karma, budaya, dan adat istiadat. Dari konsep karakter ini munculah konsep pendidikan karakter (character education).

Dalam pembentukan karakter individu dipengaruhi oleh 2 faktor yaitu faktor bawaan (genetik) dan faktor lingkungan/binaan (Kemendiknas, 2011). Namun pada prosesnya, sebenarnya yang lebih banyak mempengaruhi adalah faktor lingkungan/ binaan, faktor bawaan (genetik) hanya akan muncul pada saat individu dihadapkan pada satu kondisi yang darurat atau genting saja, namun tentu saja tingkat kegentingan satu individu dengan individu yang lain berbeda, sesuai dengan pengalaman dan kematangan individu masing-masing. Oleh karena faktor binaan dan lingkungan menjadi faktor yang lebih banyak mempengaruhi pembentukan karakter individu, maka peran pendidikan dan lembaga pendidikan di sini menjadi sangat penting untuk membangun karakter positif pada diri individu (Hakam, 2015).

Selama bertahun-tahun, ada beberapa upaya untuk mendefinisikan pendidikan karakter. Lickona (1997) mendefinisikan pendidikan karakter sebagai usaha yang disengaja untuk menumbuhkan kebaikan. Howard, et.al., (2004) mendefinisikan pendidikan karakter sebagai upaya untuk mempersiapkan individu untuk membuat penilaian etis atas setiap tindakannya, yaitu melakukan apa yang orang anggap harus dilakukan. Oleh karena itu, Howard et.al. (2004) mencatat bahwa pendidikan karakter secara signifikan mempersiapkan peserta didik untuk membuat keputusan yang baik karena mereka akan menghadapi berbagai masalah dan tantangan dalam hidup.

Sedangkan bagi Khan (dalam Aprily \& Solehudin, 2018) Pendidikan karakter adalah pendidikan yang mengajarkan kebiasaan cara berpikir dan perilaku yang membantu individu untuk hidup dan bekerjasama sebagai anggota keluarga, masyarakat, dan warga negara, serta membantu individu untuk membuat keputusan yang dapat dipertanggungjawabkan. Dapat peneliti simpulkan dari ketiga pendapat di atas, bahwa pendidikan karakter terutama dalam konteks $\mathrm{RA} / \mathrm{TK}$ adalah upaya mengembangkan perilaku anak 
untuk melakukan perbuatan-perbuatan baik melalui pembiasaan dan mempraktikannya dalam kehidupan sehari-hari.

Menurut Lickona (1997) pendidikan karakter mencakup tiga unsur pokok, yaitu mengetahui kebaikan (knowing the good), mencintai kebaikan (desiring the good), dan melaku $\urcorner$ kan kebaikan (doing the good). Maka pendidikan karakter yang baik harus melibatkan bukan saja aspek pengetahuan yang baik (moral knowing), akan tetapi juga merasakan dengan baik (moral feeling), dan akhirnya menjadi perilaku yang baik (moral action). Apabila digambarkan unsur-unsur dari karakter baik yang menyatu dalam kehidupan seseorang adalah seperti di bawah ini:

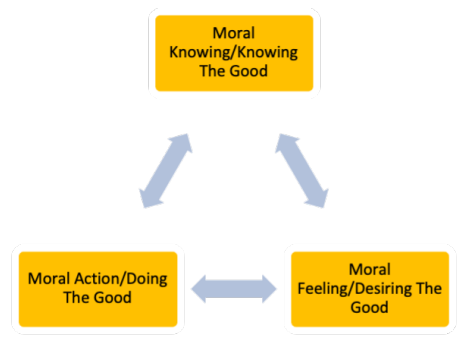

Gambar 1. Keterkaitan antar komponen karakter (Lickona, 2012)

Moral knowing diindikasikan dengan kesadaran moral termasuk memahami mana yang baik dan mana yang tidak baik, pengetahuan nilai, pengetahuan tentang landasan moral, penalaran moral, pengambilan keputusan, dan pengenalan diri. Hal ini berarti pendidik harus mampu mengembangkan kemampuan peserta didik untuk mengetahui berbagai situasi yang akan dihadapi, dilatih untuk memilih hal yang benar untuk dilakukan dan kemudian melakukannya Sedangkan moral feeling diindikasikan dengan hati nurani, harga diri, empati, mencintai kebaikan, pengendalian diri, dan rendah hati. Terakhir moral action tampak dalam kompetensi, kemauan, dan kebiasaan untuk melakukan apa yang diketahui dan dirasakan dengan mempertimbangkan segala keadaan dan fakta yang relevan untuk kemudian memiliki kehendak untuk bertindak. Singkatnya karakter yang baik adalah gambaran pribadi yang utuh, memiliki indentitas moral yang jelas (Isnarmi, 2016).

Lembaga pendidikan atau sekolah merupakan tempat ideal dalam membentuk aspek-aspek penting dalam pendidikan karakter tersebut, bahkan pembentukan dan penanaman nilai-nilai karakter itu sendiri harus dilakukan sejak usia dini.

Setiap orang harus membangun karakter solidnya sendiri, tetapi bagi orang yang belum dewasa dalam hal ini anak-anak TK/RA sangat membutuhkan bantuan orang lain agar proses penanaman nilai-nilai karakternya dapat berjalan dengan baik. Koesoema (2007) menjabarkan ada lima unsur yang perlu dipertimbangkan dalam pendidikan karakter pada anak usia dini, yaitu 1) mengajarkan, 2) keteladanan, 3) menentukan prioritas, 4) praktis prioritas, dan 5) refleksi. Kelima unsur ini menjadi pedoman dan patokan dalam menghayati dan mencoba menghidupi pendidikan karakter di dalam setiap lembaga pendidikan terutama pada jenjang TK/RA.

Proses internalisasi nilai-nilai karakter terhadap individu harus berjalan maksimal, Rasulullah SAW telah memberikan contoh pembinaan karakter akhlak manusia yang komprehensif, sebagaimana yang dikemukakan oleh Hakam (2015) diantaranya:

Keteladanan, artinya pada tahap awal siapa pun harus belajar moral dan karakter melalui percontohan, dan dalam mencontoh diperlukan figur yang patut dicontoh, guru dan orang tua dituntut untuk menjadi panutan dan pribadi yang menampilkan nilai-nilai moral.

Pembiasaan, artinya perilaku baik perlu dibiasakan, bukan merupakan pilihan, tetapi menjadi keharusan. Pembiasaan perbuatan baik harus terus menerus bukan situasional. Terjadinya inkonsistensi perbuatan moral, sering mendorong anak untuk memilih tindakan immoral. Untuk itulah diperlukan adanya suasana yang kondusif di sekolah dan keluarga agar nilai moral dapat teraplikasikan dalam setiap tindakannya.

Sosialisasi, yaitu menyampaikan nilai moral pada publik, baik melalui pengajaran, ceramah, khotbah, slogan, simbolisasi, berita, yang sifatnya selalu mengingatkan individu agar berbuat kebajikan.

Motivasi moral, yaitu menghadapkan individu atau kelompok pada sejumlah pilihan (baik perilaku maupun pertimbangan) yang sifatnya dilematis. Dilema moral seperti ini untuk mengokohkan prinsip moral yang telah ada pada diri individu, sehingga pada situasi apapun orang akan tetap konsisten berlaku bijak, tanpa memperhatikan situasi dan kondisi serta risiko yang diterimanya. Pribadi yang berprinsip inilah yang diupayakan melalui Pendidikan Karakter, sehingga moralitas dan akhlakul karimah akan menjadi watak seseorang.

Keempat indikator dan langkah pendidikan karakter tersebut harus terus menerus dilakukan oleh pendidik dalam hal ini pendidik di sekolah dan orang tua, terutama langkah pertama dan kedua harusnya menjadi bagian integral dari kepribadian para pendidik, peran ketiga dan keempat sebaiknya dilakukan melalui metode Pendidikan Nilai dan Moral yang bervariasi, sehingga peserta didik dilatih mengklarifikasi nilai, 
dibiasakan menghadapi dilema moral, menggunakan pertimbangan moral yang semakin matang, dan mampu menganalisis nilai sosial (Hakam, 2015).

Oleh karena itu, dibutuhkan kesungguhan, kesadaran, dan kerja keras dari seluruh warga madrasah/RA agar pelaksanaan pendidikan karakter dapat berhasil. Sedangkan fokus penelitian ini adalah untuk mengungkap dan mendeskripsikan mengenai nilai-nilai filosofis pesantren Pondok Iqro yaitu cageur, bageur, bener, pinter, tur singer yang menjadi landasan filosofis RA Qurratu 'Aini dalam melaksanakan pendidikan karakter kepada para peserta didiknya.

\section{METODE PENELITIAN}

Penelitian ini adalah jenis penelitian lapangan dengan pendekatan kualitatif. Kirk dan Miller (dalam Moleong, 2009) mendefinisikan penelitian kualitatif sebagai tradisi khusus dalam ilmu sosial yang secara fundamental tergantung pada pengamatan manusia baik dalam wawasan maupun dalam peristilahan.

Pendekatan kualitatif yang dipergunakan dalam penelitian ini untuk mengetahui dan mendeskripsikan secara jelas dan rinci tentang filosofi pengasuhan Sunda yaitu cageur, bageur, bener, pinter, tur singer dan pelaksanaan pendidikan karakter di Raudhatul Athfal (RA) Qurratu 'Aini. Maka peneliti melakukan serangkaian kegiatan di lapangan mulai dari penjajakan ke lokasi penelitian, studi orientasi, dan dilanjutkan dengan studi secara terfokus di RA Qurratu 'Aini.

Penelitian ini menggunakan desain penelitian studi kasus. Dalam penelitian deskriptif, menurut Rianto (2004) ada empat tipe penelitian yaitu penelitian survey, studi kasus, penelitian korelasional, dan penelitian kasual. Fokus penelitian ini adalah mendeskripsikan secara mendalam bagaimana filosofi pengasuhan Sunda cageur, bageur, bener, pinter, tur singer dalam membentuk karakter siswa dan pelaksanaannya di RA Qurratu 'Aini. Oleh karena itu, penelitian ini menggunakan penelitian deskriptif tipe ke-2 yaitu studi kasus, di mana peneliti terlibat dalam penelitian penelitian secara langsung, mendalam serta melakukan analisis data penelitian secara menyeluruh terhadap setiap perilaku individu maupun kegiatan dan peristiwa yang terjadi di dalam pesantren Cipari.

Fokus studi kasus adalah spesifikasi kasus dalam suatu kejadian baik itu yang mencakup individu, kelompok budaya ataupun suatu potret kehidupan (Creswell, 2014). Tugas peneliti dalam penelitian studi kasus adalah mengamati suatu peristiwa yang melibatkan orang/pelaku dalam satu adegan sosial pada tempat dan waktu tertentu. Maka, dalam hal ini peneliti mengamati peristiwa serta kejadian yang melibatkan 1 orang Kyai (pimpinan yayasan), 1 orang pimpinan lembaga/kepala sekolah, 2 orang guru, dan 2 perwakilan dari pihak orang tua.

Guna menjaring dan mengumpulkan data penelitian yang dibutuhkan serta pedoman/instrumen data yang digunakan yang melibatkan sumber-sumber data dalam penelitian ini, secara lebih rinci dapat dilihat pada tabel di bawah ini:

Tabel 1.

Indikator dan Penjaringan Data

\begin{tabular}{|c|c|c|}
\hline $\begin{array}{l}\text { Masalah } \\
\text { Penelitian }\end{array}$ & $\begin{array}{l}\text { Sumber data/ } \\
\text { informasi }\end{array}$ & $\begin{array}{l}\text { Bentuk pedoman/ } \\
\text { instrumen }\end{array}$ \\
\hline $\begin{array}{l}\text { Bagaimanakah } \\
\text { Landasan } \\
\text { Filosofis yang } \\
\text { mendasari } \\
\text { pelaksanaan } \\
\text { pendidikan } \\
\text { karakter di RA } \\
\text { Qurratu 'Aini? }\end{array}$ & $\begin{array}{l}\text { - Seorang Kyai } \\
\text { (pimpinan } \\
\text { yayasan) } \\
\text { - Kepala } \\
\text { Sekolah RA } \\
\text { Qurratu 'Aini } \\
\text { - } 2 \text { orang guru } \\
\text { RA Qurratu } \\
\text { 'Aini }\end{array}$ & $\begin{array}{l}\diamond \text { Pedoman } \\
\text { wawancara } \\
\diamond \text { Studi dokumentasi } \\
\diamond \text { Dibantu dengan } \\
\text { alat perekam } \\
\text { (HP) dan catatan } \\
\text { lapangan }\end{array}$ \\
\hline
\end{tabular}

\begin{tabular}{lll}
\hline Bagaimanakah & - Seorang Kyai & $\diamond$ Pedoman \\
pelaksanaan & (pimpinan & wawancara \\
pendidikan & yayasan) & $\diamond$ Pedoman \\
karakter di RA & - Kepala & observasi \\
Qurratu 'Aini? & Sekolah RA & $\diamond$ Studi dokumentasi \\
& Qurratu 'Aini & $\diamond$ Dibantu dengan \\
& - 2 orang guru & alat perekam \\
& RA Qurratu & (HP) dan catatan \\
& 'Aini & lapangan \\
& - 2 orang per- & \\
& wakilan orang & \\
& tua & \\
& Kegiatan & \\
& pembiasaan & \\
& karakter RA & \\
& Qurratu 'Aini & \\
&
\end{tabular}

Teknik triangulasi sumber data yang dimaksudkan dalam penelitian ini agar dalam pengumpulan data peneliti menggunakan multi sumber data, yakni dengan menggunakan sumber data dalam bentuk informasi yang didapatkan melalui wawancara dengan Kyai, kepala sekolah, staf pengajar dan juga perwakilan orang tua siswa, peristiwa-peristiwa yang terjadi di RA Qurratu 'Aini yang didapatkan melalui observasi terhadap kegiatan-kegiatan yang dilakukan siswa, latihan dan pembiasaan nilai-nilai karakter, serta perilaku pimpinan sekolah dan para staf pengajar (guru) dalam memberikan keteladanan bagi para 
siswanya sebagai upaya mendidik dan membina karakter siswa RA Qurratu 'Aini, dan informasi melalui dokumen dokumen-dokumen pendukung lainnya.

Analisis data dilakukan dalam beberapa tahap, yaitu: mengorganisasikan data, mendeskripsikannya ke dalam unit, mensintesis, menyusun ke dalam pola, dan membuat kesimpulan yang dapat diceritakan kepada orang lain, karena mengolah dan menganalisis data adalah upaya untuk mengatur data secara sistematis (Moleong, 2009).

\section{HASIL DAN PEMBAHASAN}

Hasil

Hasil Dalam penelitian ini, penelitian mendapatkan hasil yang akan dibahas dalam dua poin utama yaitu:

1. Landasan filosofis yang mendasari pelaksanaan pendidikan karakter di RA Qurratu 'Aini kota Bandung

2. Penyelenggaraan pendidikan karakter di RA Qurratu ‘Aini

Tabel 2.

Temuan Penelitian

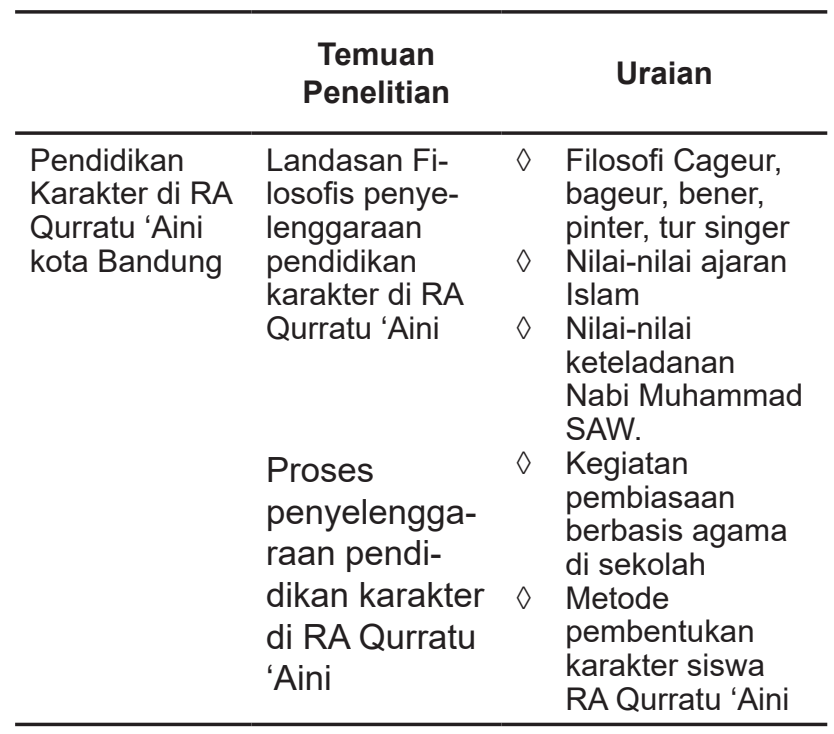

\section{Pembahasan}

\section{Landasan Filosofis yang Mendasari Pelaksanaan Pendidikan Karakter di RA Qurratu 'Aini}

Setiap lembaga pendidikan tentu mempunyai tujuan bukan hanya untuk mencetak lulusan yang unggul dan cerdas dalam bidang akademik, namun juga ingin menghasilkan manusia yang beradab serta memiliki karakter dan perilaku yang mulia. Begitu pun RA Qurratu 'Aini Kota Bandung sebagai lembaga pendidikan Islam formal dibawah naungan pesantren Pondok Iqro memiliki tujuan yang sama yaitu menghasilkan lulusan-lulusan yang memiliki pemahaman dan pengetahuan agama yang unggul, juga menjadi pribadi yang berakhlak yang mulia (akhlakul karimah) sesuai dengan tuntunan Nabi Muhammad SAW.

Pendidikan karakter atau dalam terminologi pesantren Pondok Iqro lebih dikenal dengan istilah pendidikan akhlak merupakan hal yang sangat penting, dan telah dilakukan sejak lama oleh pesantren Pondok Iqro dan juga RA Qurratu 'Aini kepada para santri dan siswa-siswinya. RA Qurratu 'Aini dalam menjalankan proses pendidikan dan pembinaan akhlak kepada para peserta didiknya bukan merupakan sesuatu yang tiba-tiba, melainkan lahir dari pemikiran-pemikiran mendalam dari pendirinya yang kemudian menjadi dasar bagi RA Qurratu 'Aini dalam menyelenggarakan pendidikan akhlak kepada para peserta didiknya.

Memiliki akhlak dan karakter yang baik merupakan perintah Allah yang terkandung dalam al-Qur'an juga hadits Nabi Muhammad SAW, alQur'an adalah sumber nilai utama orang islam yang di dalamnya banyak sekali ayat-ayat mengenai perintah Allah agar manusia memiliki dan menjadi seseorang yang berakhlak, beradab dan beretika baik dalam hubungannya terhadap Allah (hablumminallah) maupun hubungan antar sesama manusia (hablumminannas), sedangkan Nabi Muhammad adalah contoh terbaik bagi manusia bagaimana dalam bersikap dan berakhlak pada kehidupan sehari-hari. Berdasarkan hasil wawancara, menurut Pimpinan Pesantren Pondok Iqro dan Kepada Madrasah (RA Qurratu 'Aini) dalam sebuah hadits Nabi Muhammad SAW bersabda "Takhollaqu bi Akhlaqillah" yang artinya manusia itu harus memiliki akhlak seperti akhlaknya Allah SWT, namun karena manusia adalah makhluk (ciptaan) sedangkan Allah adalah Kholik (yang menciptakan) maka mustahil bagi manusia untuk melakukannya, namun setidaknya manusia dapat mencontoh sedikitnya tentang bagaimana akhlak yang baik dari seorang Nabi Muhammad SAW yang digelari uswatun hasanah (suri teladan yang baik) dan dikatakan oleh Allah dalam al-Qur'an "Innaka La'ala Khuluqin 'Adzim" yang artinya bahwa nabi Muhammad SAW adalah sebaik-baiknya akhlak di muka bumi ini. RA Qurratu 'Aini meyakini apabila peserta didik ingin memiliki akhlak yang baik maka akhlak Nabi Muhammad merupakan rujukan utama yang harus diikuti dan diteladani karena Nabi Muhammad adalah sebaikbaiknya akhlak di dunia ini.

Selain itu, Kepala madrasah menjelaskan 
bahwa fungsi dan tujuan utama Nabi Muhammad SAW diutus oleh Allah SWT kemuka bumi ini adalah "Innama Bu'itstu Li Utammima Makaarimal Akhlaq" yang artinya bahwa tugas utama Nabi Muhammad di dunia ini adalah untuk menyempurnakan akhlak manusia. Akhlak yang baik merupakan salah satu ajaran (syari'at) dalam ajaran Islam, begitu pentingnya akhlak manusia sehingga tugas utama Nabi Muhammad pun adalah untuk menyempurnakan akhlak manusia.

RA Qurratu 'Aini sebagai lembaga pendidikan agama Islam, yang di dalamnya selain ada tenaga pendidik dan kependidikan juga terdapat unsur Kyai dan ulama yang memiliki kewajiban untuk melanjutkan tugas dan misi Nabi Muhammad tersebut, karena ulama adalah pewaris para Nabi. Pimpinan Pesantren Pondok Iqro mengungkapkan dalam sebuah wawancara, bahwa tugas utama pesantren dan RA Qurratu 'Aini adalah mendidik dan membina akhlak para santri dan peserta didiknya hingga nantinya mampu menghasilkan generasi-generasi Islam yang berakhlak mulia, sesuai dengan dengan ajaran agama dan tuntunan Nabi Muhammad SAW. la juga menjelaskan bahwa ada pepatah arab yang berbunyi "Tsamrotul 'ilmi al-Adab" artinya buah dari ilmu adalah adab dan akhlak yang baik, RA Qurratu 'Aini sebagai tempat para siswa belajar dan memperoleh ilmu baik itu ilmu agama maupun ilmu pengetahuan umum, hasil yang diharapkan adalah semakin tinggi ilmu seorang santri maka harus menghasilkan akhlak yang semakin baik pula dalam hidupnya.

Sehingga dapat dikatakan bahwa mendidik dan membina karakter para peserta didiknya merupakan kewajiban dalam ajaran (syari'at) agama Islam yang harus dijalankan oleh RA Qurratu 'Aini sebagai realisasi dan perwujudan dari tugas dan tujuan utama Nabi Muhammad SAW diutus oleh Allah ke dunia ini.

Aspek yang tidak dapat dilepaskan dari muatan konsep, kurikulum, dan pembelajaran pendidikan karakter adalah aspek keagamaan atau religiusitas, baik dalam wujud, ajaran, prinsip moral, maupun value yang diusung. Bahkan, agama dapat menjadi sumber yang tidak akan ada habis-habisnya dalam membangun rumusan, konsep, gagasan, dan bahan ajar pendidikan karakter (Maemonah, 2012). Hal senada dikemukakan oleh Michael Novak (dalam Lickona, 2012), menjelaskan bahwa proses identifikasi tentang karakter tidak dapat dilepaskan dari tradisi dan landasan keagamaan. Meskipun memang hanya sekedar menunjukkan posisi agama tanpa menjelaskan bagaimana peran agama sendiri dalam pendidikan karakter, namun pandangan tersebut menegaskan bahwa agama tidak dapat dilepas sama sekali dari perbincangan tentang karakter.

Selanjutnya posisi dan peran agama dalam pendidikan karakter di RA Qurratu 'Aini, selain menjadi landasan utama juga menjadi kontributor nilai-nilai kebaikan yang terkandung dalam ajaran agama Islam untuk kemudian ditanamkan dan dibiasakan dalam kehidupan sehari-hari peserta didik selama di sekolah maupun luar sekolah. Tanpa menempatkan agama sebagai salah satu aspek dalam merumuskan tujuan dan penanaman nilai-nilai di dalamnya, akan menjadikan pendidikan karakter kering dari nuansanuansa dinamis di dalamnya (Karim, 2017). Dalam perspektif agama, pendidikan terkait dengan suatu nilai ketuhanan (teologis), untuk itu pendidikan merupakan perpaduan antara keunggulan spiritual dengan kultural. Dengan demikian, manusia yang berkomitmen beragama, sebagai wujud ketaatan terhadap ajaran agama, akan mendorong terbentuknya kepribadian yang memiliki good character baik dalam konteks individual maupun sosial, dan Madrasah Ibtidaiyah pada umumya memiliki warna yang memadukan antara keunggulam spiritual dan juga kultural tersebut.

Meskipun demikin, bukan berarti sekolah mengabaikan standar atau ukuran baik dan buruk selain yang bersumber al-Qur'an dan hadits Nabi dalam menentukan nilai-nilai karakter dan akhlaknya yang akan ditanamkan kepada para peserta didiknya. Standar lain yang dimaksud adalah hati nurani, akal, tradisi, budaya, adat istiadat yang disepakati nilainya oleh masyarakat selama tidak bertentangan dengan ajaran al-Qur'an dan sunnah Nabi Muhammad SAW.

Kepala sekolah, staf pengajar, dan juga orang tua siswa melalui sebuah wawancara juga menegaskan bahwa pendidikan karakter itu adalah sesuatu yang sangat penting untuk hidup mereka. Landasan filosofis pendidikan karakter pesantren Pondok lqro dituangkan menjadi visi dan misinya RA Qurratu 'Aini yaitu "Mencetak Generasi Islam yang Cageur, Bageur, Bener, Pinter, tur Singer untuk Membangun Umat dan Bangsa".

Apabila diperhatikan visi dan misi diatas yang diambil dari filosofi "Sunda" dan menjadi karakter utama orang "Sunda" ini menghasilkan 5 prinsip karakter yang harus dimiliki para siswa RA Qurratu 'Aini, yang menurut Kepala RA Qurratu 'Aini dijelaskan sebagai berikut:

01. "Cageur" atau Sehat. Mencerminkan karakter siswa yang sehat secara jasmani maupun rohani, namun secara lebih mendalam memiliki makna bahwa siswa harus mampu berpikir rasional dan proporsional dengan dilandaskan pada nilai-nilai moral Islam yang mulia. 
02. "Bageur" atau baik. Mencerminkan karakter siswa yang memiliki sifat kemanusiaan, menjujung akhlak mulia terhadap sesama manusia yang berlandaskan atas rasa kasih dan sayang.

03. "Bener" atau Benar. Mencerminkan karakter siswa yang amanah, jujur, tidak berkhianat, dan tidak pernah berbohong.

04. "Pinter" atau pintar. Mencerminkan santri yang berilmu, baik dalam ilmu pengetahuan umum dan utamanya ilmu agama, yang dengan ilmu yang dimiliki oleh para siswa akan mengantarkan pada keberkahan dunia, yang berpangkal pada kemuliaan hidup untuk berkal di akhirat.

05. "Singer" atau mawas diri. Mencerminkan siswa yang bertoleransi, ramah, menghargai perbedaan dan mendahulukan kepentingan orang lain dibandingkan kepentingan diri sendiri.

Nilai "Cageur" misalnya, pihak sekolah selalu melaksanakan kegiatan rutin senam SKJ setiap hari Jum'at pada pukul 08.00-09.00 WIB sebagai kegiatan pembiasaan kepada para siswanya, juga melaksanakan konsultasi dan layanan kesehatan dengan melakukan kerjasama dengan Puskesmas setempat setiap minggu pertama setiap bulan. Setiap siswa wajib menjaga kebersihan mulai dari kebersihan dan kerapihan diri sendiri, seperti kebersihan seragam sekolah, kuku, gigi, rambut, dan juga kebersihan lingkungan kelas dan sekolah pada umumnya. Namun di masa pandemi covid-19 ini, pihak sekolah menggantinya dengan mewajibkan siswa untuk melakukan olah raga dan senam ringan yang direkam melalui video untuk dikirimkan kepada masing-masing gurunya.

Kemudian nilai "Bageur", sekolah mengajarkan dan menanamkannya dengan cara melaksanakan kegiatan sosial kemasyarakatan dengan membantu orang-orang yang membutuhkan dengan program yang disebut "Program Sahuap" dimana setiap 1 bulan sekali siswa akan mengumpulkan uang jajannya seikhlasnya setiap hari Jum'at melalui kencleng keliling, lalu kemudian uang tersebut dibelikan beras untuk dibagikan kepada masyarakat yang membutuhkan, dan sebelum masa pandemi covid-19 siswa biasanya terlibat langsung untuk membagikannya. Hal ini untuk menumbuhkan kesadaran dan rasa kepedulian serta empati terhadap kondisi dan keadaan disekitarnya yang kondisi hidupnya ada dalam kesulitan, karena ia merupakan bagian dari lingkungan masyarakatnya maka siswa RA Qurratu 'Aini harus bermanfaat dan menebar kasih sayang kepada orang lain khususnya di era pandemi COVID-19 seperti sekarang ini.

Nilai "Bener", proses pengembangan dan penanaman nilainya pihak sekolah membiasakannya kepada kegiatan sehari-hari yang didaptasi dari nilainilai karakter yang terdapat dalam kitab Khulasoh nurul yaqin yang membahas mengenai keteladanan akhlak Nabi Muhammad SAW secara universal yang dibutuhkan oleh peserta didik dalam kehidupan sehari-hari, Saiful (2016) dalam hasil penelitiannya menguraikan bahwa ada 4 nilai karakter yang terkandung dalam kitab tersebut, yaitu sebagai berikut:

01. Shiddiq (Jujur)

Kejujuran Nabi Muhammad SAW tak diragukan lagi bahkan ketika usia remaja beliau ikut pamannya berdagang, ketika berdagang itulah kejujuran Nabi Muhammad SAW sampai membuat pedagang-pedagang lain kagum dibuatnya dan akhirnya beliau dinobatkan dengan gelar al-Amin. Nilai akhlaq atau karakter yang dapat diambil dan diaplikasikan dalam kehidupan sehari-hari dari sifat shidiq yaitu pendidikan kejujuran. Sikap jujur termasuk akhlak yang terpuji dan mulia. Sebagai umat Nabi Muhammad SAW, peserta didik harus meneladani sifat jujur beliau, dengan cara mengaplikasikan dalam kehidupan sehari-hari yaitu senantiasa membiasakan diri bersikap jujur dalam segala hal, baik dalam perkataan, dan perbuatan.

02.Amanah (terpercaya)

Nilai akhlak yang dapat diambil dan diaplikasikan dalam kehidupan sehari-hari dari sifat amanah yaitu membentuk peserta didik menjadi siswa yang amanah dan adil. Amanah merupakan sesuatu yang harus dijaga dan disampaikan kepada yang berhak menerimanya. Sedangkan keadilan adalah tidak berat sebelah atau tidak memihak atau menempatkan sesuatu pada tempatnya.

Sebagai umat Nabi Muhammad SAW, peserta didik harus meneladani sifat amanah dan keadilan beliau, dengan cara mengaplikasikan dalam kehidupan sehari-hari yaitu dengan mengikhlaskan ibadah kepada Allah SWT, memperbaiki hubungan, berlaku adil sesama manusia dan lingkungan sekitar, adil dan amanah dalam menyerahkan setiap hak pada yang berhak menerimanya, semua itu adalah bagian dari amanah dan keadilan.

03. Tabligh (menyampaikan)

Nilai pendidikan akhlak yang dapat 
diambil dan diaplikasikan dalam kehidupan sehari-hari dari sifat tabligh yaitu membentuk karakter siswa menjadi pribadi yang sabar. Kesabaran Rasulullah SAW dapat terlihat dalam perjuangan beliau yang tidak pernah mengenal lelah dan putus asa dalam menyampaikan wahyu dan mengajarkan kepada umat manusia yang di terimanya dari Allah SWT, sekalipun menghadapi banyak cobaan, hambatan, gangguan, serta rintangan yang luar biasa.

Sebagai umat Nabi Muhammad SAW, peserta didik harus meneladani kesabaran beliau, dengan cara mengaplikasikan dalam kehidupan sehari-hari yaitu dengan belajar untuk menyeimbangkan antara perasaan dan pikiran.

\section{Fathonah (Cerdas)}

Nilai-nilai pendidikan akhlak yang dapat diambil dan diterapkan dalam kehidupan seharihari dari sifat fathonah yaitu membentuk karakter siswa yang memiliki jiwa kepemimpinan. Nabi Muhammad SAW adalah pemimpin umat yang tangguh, efektif dan cerdas. Segala macam kualitas yang dibutuhkan untuk tampil sebagai figur kepemimpinan terhimpun pada pribadi Muhammad SAW, hal ini terlihat saat peristiwa peletakan hajar aswad, terbukti bahwa Rasulullah mampu menyelesaikan perselisihan antara kaum Quraisy tersebut dengan damai.

Sebagai umat Nabi Muhammad SAW, peserta didik harus meneladani sifat kepemimpinan beliau dengan cara mengaplikasikan dalam kehidupan seharihari, yaitu menjadi pemimpinan yang baik dan menjadi pemimpin yang mampu berpikir dengan cerdas.

Nilai-nilai itu ditanamkan dan dibiasakan dalam kegiatan pembelajaran siswa di sekolah, membuat dan mengerjakan pekerjaan sekolahnya sendiri, tepat waktu untuk melaksanakan sholat berjamaah di masjid, membaca bismillah sebelum dan sesudah melakukan kegiatan, mengucapkan salam dan mencium tangan guru apabila bertemu.

Nilai "Pinter" dan "singer", penanaman karakter ini dilakukan oleh RA Qurratu 'Aini melalui pembelajaran yang menyeimbangkan antara pelajaran umum dan pelajaran agama yang didapatkan oleh siswa. Para siswa juga diberikan pembelajaran keagamaan seperti membaca iqro, menghafal doa dan surat-surat pendek al-qur'an, karena RA Qurratu 'Aini berada dalam naungan pesantren Pondok Iqro.
Menurut al-Zarnuji (dalam Zainudin, Ali \& Mujtahid (eds.) 2009) peserta didik dalam menempuh pendidikan harus dibekali dengan akhlak yang baik agar peserta didik tidak terpalingkan dengan masalah-masalah dunia yang remeh, kecil, dan merusak. Peserta didik jangan sampai merendahkan diri dengan mengharapkan memperoleh suatu yang tidak semestinya, serta mencegah dirinya dari halhal yang merendahkan ilmu, ia harus berbuat tawadu' yaitu sifat tengah-tengah antara sombong dan kecil hati.

Selain itu pimpinan yayasan mengungkapkan bahwa tujuan didirikannya RA Qurratu 'Aini adalah untuk mencetak generasi masa depan Islam yang utuh baik dari segi pengetahuan, karakter dan akhlak yang mulia, serta memiliki pemahaman agama yang mumpuni. Sebagaimana pendapat yang diungkapkan oleh Lickona (1997) yang mendefinisikan pendidikan karakter sebagai usaha yang disengaja untuk menumbuhkan kebaikan. Demikian juga dengan pendapat Zubaiedi (2012) yang menyatakan bahwa sekolah tidak hanya berkewajiban meningkatkan pencapaian akademis, tetapi juga bertanggungjawab dalam pembentukan karakter yang baik merupakan dua misi integral yang harus mendapat perhatian sekolah.

Secara filosofis, Karim (2017) menjelaskan bahwa pembangunan karakter bangsa merupakan sebuah kebutuhan asasi dalam proses berbangsa karena hanya bangsa yang memiliki karakter dan jati diri yang kuat yang akan eksis dan mampu bersaing dengan negara lain.

Menurut kepala sekolah RA Qurratu 'Aini, landasan filosofis pendidikan karakter di atas sangat erat kaitannya dengan ajaran Islam yang ada dalam al-Qur'an, al-Hadits, dan kisah-kisah keteladanan Nabi-Nabi dan juga para ulama besar. Inti dari karakter seluruh siswa di RA Qurratu 'Aini adalah Iman kepada Allah SWT yang kemudian diimplementasikan melalui ibadah dan akhlak yang baik dan mulia.

Berdasarkan hasil wawancara terhadap staf pengajar dan orang tua siswa, mereka memandang bahwa kemandirian dan kesederhanaan merupakan karakter yang sangat penting diajarkan di RA Qurratu 'Aini. Melalui kegiatan ekstrakurikuler seperti kesenian tari, menggambar, makan Bersama, 
dan pencak silat dimana siswa ditanamkan nilainilai kemandirian dan cara berorganisasi yang baik, dilatih untuk bertahan dalam situasi sulit, tidak mudah menyerah dalam keterbatasan, empati dan bekerja keras. Sedangkan nilai kesederhanaan ditanamkan dan dibiasakan oleh guru dengan melarang siswa untuk membawa uang bekal dari rumah lebih dari Rp. 5000., siswa dilarang menggunakan pakaian dan perhiasan yang berlebihan, harus membawa bekal sendiri dari rumah, dan saling berbagi bekal dengan sesama teman yang lain. Salah satu nilai luhur pesantren Pondok Iqro dan menjadi pedoman perilaku bagi warga pesantren dan RA Qurratu 'Aini secara keseluruhan adalah penampilan sederhana. Sederhana yang dimaksud di sini bukan identik dengan kemiskinan, tetapi kemampuan bersikap dan berpikir wajar, proporsional, dan tidak tinggi hati.

Beberapa temuan ini sama dengan penelitian yang dilakukan oleh LukensBull (2017) tentang pengajaran moralitas dalam pendidikan Islam di Jawa, di mana ia menggambarkan nilai-nilai seperti tidak mementingkan diri sendiri, kesederhanaan, dan kemandirian sebagai inti bagi semua aspek kehidupan Pesantren dan lembaga pendidikan Islam termasuk madrasah pada umumnya.

\section{Penyelenggaraan Pendidikan Karakter di RA Qurratu 'Aini Kota Bandung}

Data dari hasil observasi dan wawancara terhadap pimpinan yayasan pesantren, kepala madrasah, staf pengajar, perwakilan orang tua siswa, serta dokumen-dokumen pendukung lainnya diperoleh hasil bahwa proses pembentukan karakter di RA Qurratu 'Aini tidak hanya diberikan ketika jam pelajaran dikelas saja, melainkan diperkuat kembali diluar setelah selesai pembelajaran para siswa mendapatkan pendidikan untuk menambah pengetahuan mereka tentang nilai-nilai agama diluar jam pelajaran formal, sekaligus pembiasaan agar nilai-nilai karakter tertanam menjadi suatu kepribadian yang kuat.

Adapun kegiatan-kegiatan berbasis pembiasaan RA Qurratu Aini sebagai proses pembentukan karakter santri adalah sebagai berikut:

01.Pembiasaan Solat Berjamaah Siswa

Kegiatan Salat berjamaah bagi para siswa di RA Qurratu 'Aini berlangsung secara rutin setiap harinya. Peneliti melakukan pengamatan langsung di madrasah tentang aktifitas solat berjamaah ini. Ada dua tempat berlangsungnya solat berjamaah ini, yaitu masjid dan kelas masing-masing. Pelaksanaan solat dhuha misalnya, seluruh siswa wajib dan dibiasakan melaksanakan solat berjamaah di kelasnya masing-masing. Sedangkan untuk solat Dzuhur dan Ashar, seluruh siswa melaksanakannya secara berjamaah di mesjid sekolah dan didampingi oleh guru-gurunya. Dalam sebuah wawancara dengan guru dan orang tua siswa. Pada awalnya mereka mengungkapkan bahwa anak-anaknya merasa sangat kesulitan dan berat sekali untuk melakukan solat berjamaah dhuha dan dzuhur tersebut. Tentu memerlukan kesabaran dari para guru dalam membimbing anak-anak usia dini untuk dapat melaksanakan sholat berjamaah secara tertib, karena dunia anak adalah dunia bermain sehingga kadang dalam pelaksanaannya anak-anak masing sering bermain. Namun setelah lama kelamaan menjadi terbiasa untuk solat berjamaah baik dimasjid maupun di kelas. Setelah berjalan kurang lebih 1-2 bulan kegiatan solat berjamaah bukan sesuatu yang berat lagi untuk dilakukan, dan sudah menjadi kebiasaan sehari-hari yang terus dilakukan.

Menurut kepala madrasah dan staf pengajar mengungkapkan bahwa kegiatan solat berjamaah ini adalah untuk membentuk karakter disiplin dan tertib siswa, membiasakan solat berjamaah di masjid 5 waktu, dan mampu mengerjakan solat berjamaah dengan kesadaran sendiri tanpa diperintah lagi oleh guru-gurunya.

02.Pembiasaan Membaca Iqro dan surat-surat pendek

Kegiatan membaca iqro dan suratsurat pendek di RA Qurratu 'Aini merupakan sesuatu yang diharuskan, karena RA Qurratu 'Aini merupakan lembaga pendidikan Islam dibawah naungan yayasan pesantren Pondok Iqro dimana pesantren sangat memfokuskan pada pengajaran al-Qur'an, baik itu ilmu tajwid, makhorijul huruf, tahfidz, dan juga mengajarkan irama lagu Qur'an baik untuk Murrotal dan Mujawwaz (Qiro'atul Qur'an).

Khusus untuk kegiatan pembiasaan membaca iqro diwajibkan untuk seluruh siswa untuk dilakukan setiap selesai melaksanakan solat berjamaah. Menurut pengamatan yang dilakukan peneliti, kegiatan ini dilakukan di dalam dan di luar kegiatan pembelajaran 
formal madrasah dalam mempelajari huruf hijaiyah dan makhorijul huruf disetiap waktu dan kelas yang telah ditentukan. Pembiasaan membaca iqro ini dilakukan oleh siswa dalam bimbingan gurunya setelah melaksanakan solat dhuha dan dzuhur, selain itu biasanya yang dibaca siswa adalah surat-surat pendek, atau meneruskan sisa bacaan mereka masingmasing. Kegiatan ini dilakukan kurang lebih 1015 menit sebelum melanjutkan kepada kegiatan rutin dan pembelajaran madrasah lainnya. Dalam kondisi pandemic covid-19 sekarang ini, kegiatan tersebut dilakukan dirumah, dengan bekerjasama dengan pihak orang tua untuk membimbingan anak-anaknya membaca iqro dan setoran hafalan surat pendek yang sudah ditentukan oleh guru, kemudian setiap satu minggu sekali guru akan mengetes hafalannya melalui daring (zoom/goggle meet).

Pimpinan yayasan pesantren dan kepala madrasah mengungkapkan bahwa tujuan kegiatan pembiasaan membaca iqro dan suratsurat pendek ini adalah agar para santri makin lancar dalam membaca iqro, mampu mengenal huruf-huruf hijaiyah secara baik dan dalam belajar iqro pengulangan merupakan kunci utama agar lebih cepat pandai dalam membaca iqro, dan tentu peran guru menjadi sangat penting dalam membimbing dan mengatur para siswanya agar tertib dalam kegiatan tersebut.

Temuan penelitian di RA Qurratu 'Aini juga menunjukkan bahwa selain kegiatankegiatan pembiasaan di atas, madrasah dalam membentuk karakter para siswanya menggunakan tiga metode utama, yaitu pengetahuan, pengkondisian, dan praktek untuk membentuk kebiasaan santri. Hal ini sesuai dengan teori pengembangan karakter yang diungkapkan oleh Lickona (2012) bahwa pendidikan karakter mencakup tiga unsur pokok, yaitu mengeta-hui kebaikan (knowing the good), mencintai kebaikan (desiring the good), dan melaku-kan kebaikan (doing the good). Sementara itu Ningsih (2015) menjelaskan bahwa perasaan-perasaan tentang diri, orang lain, dan kebaikan itu sendiri berkombinasi dengan pengetahuan moral untuk membentuk sumber dari motivasi moral seseorang, hal ini akan membantu individu atau dalam hal ini peserta didik dari hanya sekedar tahu menjadi melakukan tindakan moral.

Kegiatan pembiasaan yang diharuskan dan dilakukan secara terus menerus dan berulang-ulang oleh para siswa di RA Qurratu 'Aini diharapkan akan membuat siswa yang awalnya belum terbiasa karena masih membawa kebiasaan di lingkungan sebelumnya, menjadi terbiasa untuk melakukan berbagai kegiatan yang diwajibkan di madrasah. Hal tersebut senada dengan pendapat Aini (2017) bahwa metode pembiasaan adalah cara yang digunakan oleh pendidik kepada peserta didik dalam proses belajar mengajar, dengan melakukan suatu perbuatan atau keterampilan tertentu secara terus menerus dan konsisten untuk waktu yang cukup lama, sehingga perbuatan atau keterampilan itu benar-benar dikuasai dan akhirnya menjadi suatu kebiasaan yang sulit ditinggalkan.

Karakter adalah gabungan dari kebiasaan-kebiasaan manusia. Kebiasaan adalah perilaku yang dilakukan tanpa harus berpikir terlebih dahulu, kebiasaan sulit berubah, tetapi bisa diubah dengan komitmen yang sungguh-sungguh (Covey, 2004). Kebiasaan (habits) yang baik adalah persinggungan antara pengetahuan (knowlegde), keahlian (skill) dan keinginan (desire). Pembiasaan merupakan sebuah metode dalam pendidikan berupa proses penanaman kebiasaan. Sementara yang dimaksud dengan kebiasaan itu sendiri adalah cara-cara bertindak yang persistent uniform dan hampir tidak diketahui oleh pelakunya (Rizal, Iqbal, \& MA, 2018).

Sementara itu, Thorndike menyebutkan bahwa untuk memperoleh hasil yang baik maka kita memerlukan latihan. Latihan yang dimaksud ialah latihan yang dilakukan secara berulang-ulang dengan urutan yang benar dan secara teratur. Teori ini merujuk kepada sistem "coba-coba", yaitu suatu kegiatan yang bila kita gagal dalam melakukannya, maka kita harus terus mencoba hingga akhirnya berhasil (Choer, 2009).

Berkowitz \& Bier (2005) menyimpulkan bahwa "effective character education is not adding a program or set of programs, rather it is a transformation of the culture and life of the school". Maksudnya, bahwa pendidikan karakter yang efektif bukan hanya tergantung dari banyaknya program yang dilakukan di sekolah, melainkan suatu transformasi budaya dan kehidupan baik di sekolah, keluarga dan lingkungan masyarakat peserta didik. 
Semua elemen yang ada dalam lingkungan RA Qurratu 'Aini harus menjaga akhlak dan mempunyai akhlak yang baik, tanpa terkecuali baik itu pimpinan pesantren, kepala sekolah, para ustadz, guru, tenaga kependidikan, dan para siswa harus memelihara dan mentaati aturan dan kultur budaya pesantren dan madrasah.

Hal tersebut senada dengan pendapat Hakam (2015) bahwa untuk menciptakan seseorang yang berkarakter (moral being) itu bukan hanya terbatas pada penyampaian moral knowing dan moral training saja melainkan harus membiasakan anak untuk terus melakukan perbuatan baik, dan untuk menciptkan moral being perlu didukung kondisi dan lingkungan sekolah yang kondusif agar nilai-nilai kebaikan itu dapat teraplikasikan. Tugas seperti itu, menuntut sekolah untuk menjadi lembaga pembudayaan nilai moral, bukan hanya sebagai lembaga pengajaran moral dan lembaga pelatihan moral.

Metode pembiasaan dan pengamalan di RA Qurratu 'Aini ini merupakan sesuatu yang berkaitan erat dengan nilai-nilai filosofis dan keagamaan yang telah dibahas sebelumnya, Islam adalah agama yang menuntut umatnya agar mengerjakan amal saleh yang di ridhoi Allah, menuntut manusia agar mengarahkan tingkah laku, naluri, dan kehidupan ini sehingga dapat mewujudkan perilaku dan akhlak yang baik. Agar perbuatan itu bisa berujung kepada amal saleh, maka dibutuhkan latihan dan pengalaman. Prinsip di RA Qurratu 'Aini mengenai ilmu yang bermanfaat adalah ilmu yang menghasilkan amal (ibadah), dan amal (ibadah) harus melahirkan akhlak yang baik.

Dalam temuan penelitian lainnya di RA Qurratu 'Aini, upaya yang dilakukan untuk mengembangkan aspek pengamalan para siswa, yang pertama adalah melalui praktek ibadah. Melalui praktek ibadah tersebut sekolah meyakini banyak nilai-nilai kebaikan yang ada di dalam setiap praktek ibadah yang akan membentuk kepribadian santri menjadi lebih baik. Hal tersebut senada dengan pendapat dari Basher (dalam Aprily, 2019b) yang menyatakan bahwa ibadah adalah metode penting dalam mendidik karakter seorang muslim, melalui ritual-ritual ibadah dan tugas-tugas praktis Islam harus dimasukkan dalam proses mendidik individu untuk menjadi seseorang yang berkarakter dan berakhlak mulia (akhlakul karimah).

Selain pembiasaan praktek ibadah, dalam temuan penelitian terungkap bahwa pelaksanaan pendidikan karakter dan penanaman nilai-nilai kebaikan di RA Qurratu 'Aini juga dilaksanakan dalam kegiatan ekstrakurikuler. Sekolah juga memiliki berbagai kegiatan ekstrakurikuler untuk para siswa, kegiatan ekstrakurikuler juga merupakan salah satu metode dalam rangka pengembangan karakter dan penanaman nilainilai kebaikan bagi siswa. Suryosubroto (2002) mengungkapkan kegiatan ekstrakurikuler adalah kegiatan yang dilakukan di luar jam pelajaran tatap muka yang dilaksanakan di sekolah atau luar sekolah untuk memperkaya dan memperluas wawasan pengetahuan dan kemampuan yang telah dipelajari dari berbagai mata pelajaran dalam kurikulum.

Dari seluruh kegiatan pembiasaan di RA Qurratu 'Aini, peneliti menemukan beberapa di antaranya sebagai berikut:

a. Sikap menghormati dan memuliakan Kyai, para ustadz, para guru dan orang yang lebih tua.

b. Taat pada perintah Kyai, ustadz, dan para guru di sekolah dan orang tua di rumah.

c. Hidup sehat dengan berolahraga dan menjaga kebersihan baik pribadi, lingkungan sekolah, serta lingkungan rumah.

d. Sholat berjamaah tepat waktu di masjid khususnya sholat dhuha dan sholat dzuhur

e. Berbicara yang sopan.

f. Hidup sederhana (tidak membawa uang jajan berlebihan dan membawa bekal sendiri dari rumah).

g. Membaca Iqro dan Menghafal al-Qur'an (muroja'ah) surat-surat pendek.

RA Qurratu 'Aini melatih dan membiasakan peserta didiknya untuk melakukan hal-hal tersebut dari sejak awal masuk ke sekolah. Para siswa akan belajar dari perlakuan yang dialaminya, serta belajar dari apa yang mereka alami sehari-hari di sekolah. 


\section{PENUTUP}

Berdasarkan temuan penelitian dan pembahasan maka dapat disimpulkan bahwa:

Pertama, untuk menanamkam nilai-nilai karakter jujur, amanah, mandiri, sederhana, empati, dan disiplin dilakukan melalui kegiatan-kegiatan pembiasaan yang dilakukan oleh para siswa di RA Qurratu 'Aini yaitu kegiatan solat berjamaah, kegiataan membaca iqro, praktik ibadah, kegiatan esktrakurikuler, mengucapkan salam apabila bertemu guru, membaca do'a sebelum dan sesudah memulai pembelajaran, tidak membawa uang jajan berlebihan, pembagian beras bagi masyarakat yang membutuhkan, dan budaya akhlaq di RA Qurratu 'Aini merupakan perangkat utama untuk membentuk karakter siswa yang dilakukan secara konsisten dan terus-menerus hingga menjadi kebiasaan siswa. Selain itu, kegiatan penguatan karakter di luar jam pelajaran di kelas juga memberi dampak positif terhadap karakter siswa.

Kedua, peran Kyai sebagai pimpinan yayasan pesantren, kepala madrasah, dan juga seluruh staf pengajar juga berperan cukup besar terhadap keefektifan pembentukan karakter siswa, hal tersebut membuat siswa mempunyai sosok teladan bagaimana berprilaku yang baik dalam kehidupan sehari-hari dan selama berada di madrasah pengaruh negatif dari luar lingkungan madrasah menjadi semakin terbatas.

Ketiga, pembentukan karakter pada jenjang RA atau anak usia dini tidak dapat dibangun dalam waktu yang singkat melainkan memerlukan proses yang begitu panjang dan konsisten, juga tidak cukup hanya dibentuk dari aspek pengetahuannya saja namun juga siswa harus mempunyai sosok yang dianggap mampu menjadi teladannya dalam berperilaku, serta didukung melalui kegiatan-kegiatan pembiasaan yang positif hingga akhirnya akan membentuk karakter siswa yang baik yang dipraktekan dalam kehidupan sehari-hari.

Hal yang masih harus dipelajari untuk penelitian ke depannya adalah bagaimana menemukan alat kontrol serta alat evaluasi untuk mengetahui keefektifan dari kegiatan-kegiatan pembiasaan siswa di RA Qurratu 'Aini, serta bagaimana pengaruh dari faktor-faktor eksternal di luar lingkungan madrasah seperti dorongan dari orang tua siswa dan dampak dari kemajuan teknologi yang berimplikasi terhadap pembentukan karakter siswa.

\section{DAFTAR PUSTAKA}

Aini, V. N. (2017). Implementasi Pendidikan Karakter Melalui Metode Pembiasaan di Kelas 3 SD Negeri 2 Blunyahan. Skripsi tidak diterbitkan. Retrieved from https://docplayer.info/66766536Implementasi-pendidikan-karakter-melaluimetode-pembiasaan-di-kelas-3-sd-negeri-2blunyahan.html

Aprily, N. M. (2019a). Nidzomul Ma'had dalam pendidikan akhlak di Pesantren Cipari Kabupaten Garut. Premiere Educandum : Jurnal Pendidikan Dasar Dan Pembelajaran, 9 (2), 141-159. DOI: 10.25273/pe.v9i2.4987

Aprily, N. M. (2019b). Pendidikan Karakter di Pesantren: Studi Kasus di Pondok Pesantren Cipari Kabupaten Garut. Jurnal Inovasi Pendidikan Dasar, 4 (2), 77-94. DOI: 10.22236/jipd.v4i2.85

Aprily, N. M., \& Solehudin, M. (2018). Pondok Pesantren and the Formation of Character Students through Activity-Based Habituation: A Case study On the Implementation of Character Education at Pesantren Pondok lqro Bandung. The 1st International Conference on Elementary Education, Proceedings 1 (1), 752-761. Retrieved from http://proceedings.upi.edu/index. php/icee/issue/view/2/2

Berkowitz, M. W., \& Bier, M. C. (2005). What works in character education: A research-driven guide for educators. St. Louis, MO: Character Education Partnership.

Choer, A. (2009). Psikolinguistik Kajian Teoretik. Jakarta: Rineka Cipta.

Cooley, A. (2008). Legislating Character: Moral Education in North Carolina's Public Schools. Educational Studies, 43, 188-205. DOI: 10.1080/00131940802117563

Covey, S. R. (2004). The seven habits of highly effective poeple: powerful lesson in personal change. In The seven habits - an overview. DOI: 10.1002/pfi.4170301009

Creswell, J. W. (2014). Research Design: Qualitative, Quantitative, and Mixed Methods Approaches. London: SAGE Publications Inc.

Hakam, K. A. (2013). Pendidikan Karakter di Sekolah Dasar. Retrived from: https://kamaabdulhakam. wordpress.com/

Hidayat, M. (2017). Analisis pendidikan akhlak dalam pandangan ibnu miskawaih. Tesis tidak diterbitkan. Makassar: UIN Alaudin. Retrieved 
from http://repositori.uin-alauddin.ac.id/8741/1/ MUHAMMAD\%20HIDAYAT.pdf.

Howard, R. W., Berkowitz, M. W., \& Schaeffer, E. F. (2004). Politics of Character Education. Educational Policy, 18 (1), 188-215. DOI: 10.1177/0895904803260031

Isnarmi, M. (2016). Pendekatan Kritis-Transformatif dalam PKn: Sebuah Upaya Pengembangan Karakter (Good Character). Budimansyah, D. \& Komalasari, K. (Eds.). Pendidikan Karakter : Nilai Inti dalam Upaya Pembinaan Kepribadian Bangsa. Bandung: Widya Aksara Press. Retrieved from http://repository.unp.ac.id/id/ eprint/196

Izfanna, D. \& Hisyam, N. A. (2012). A comprehensive approach in developing akhlaq: A case study on the implementation of character education at Pondok Pesantren Darunnajah. Multicultural Education \& Technology Journal, 6 (2), 77-86. DOI: 10.1108/17504971211236254

Karim, N. (2017). Kontribusi Tradisi Haroa dalam Pendidikan Karakter Masyarakat Buton AlIzzah: Jurnal Hasil-Hasil Penelitian, 12 (1), 94112. DOI: $10.31332 / a i . v 12 i 1.533$

Kemendiknas. (2011). Pedoman Pelaksanaan Pendidikan Karakter: Berdasarkan Pengalaman di satuan Pendidikan Rintisan. Jakarta: Kementerian Pendidikan Nasional

Koesoema, D. (2007). Pendidikan Karakter: Strategi Mendidik Anak di Zaman Global. Jakarta: Grasindo.

Lickona, T. (1997). A Comprehensive Approach to Character Building in Catholic Schools. Journal of Catholic Education, 1 (2), 158-175. DOI: 10.15365/joce. 0102051997

Lickona, T. (2012). Educating for Character. Jakarta: PT. Bumi Aksara.

Lukens-Bull, R. A. (2017). Teaching Morality: Javanese Islamic Education in a Globalizing Era. Journal of Arabic and Islamic Studies, 3, 26-47. DOI: 10.5617/jais.4554

Maemonah. (2012). Aspek-aspek dalam pendidikan karakter. Forum Tarbiyah, 10 (1), 30-42.
Retrieved from http://e-journal.iainpekalongan. ac.id/index.php/forumtarbiyah/article/view/371

Megawangi, R. (2010). Pengembangan Program Pendidikan Karakter di Sekolah: Pengalaman Sekolah Karakter. Jakarta: Universitas Terbuka. Milliren \& Messer, M. H. (2009). "Invitations" To Character. Journal of Invitational Theory \& Practice, 15, 19-31.Retrieved from https://eric. ed.gov/?id=EJ871349

Moleong, L. J. (2009). Metodologi Penelitian Kualitatif. Bandung: Remaja Rosdakarya.

Ilahi, M.T. (2014). Gagalnya Pendidikan Karakter: Analisis dan Solusi Pengendalian Karakter Emas Anak Didik. Yogyakarta: Ar-Ruzz Media.

Ningsih, T. (2015). Implementasi Pendidikan Karakter. Purwokerto: STAIN Press.

Nucci, L. (2017). Character: A Multifaceted Developmental System. Journal of Character Education, 13 (1), 1-16. Retrieved from https:// www.infoagepub.com/products/journal-ofcharacter-education-vol-13-1

Pusat Perkembangan Kurikulum. (2009). Kebijakan Nasional Pendidikan Karakter Bangsa. Jakarta: Puskur Litbang Kemendiknas.

Rianto, Y. (2004). Metodologi Penelitian Pendidikan. Surabaya: Unesa University Press

Rizal, M., Iqbal, M., \& MA, N. (2018). Model Pendidikan Akhlaq Santri di Pesantren dalam Meningkatkan Akhlaq Siswa Di Kabupaten Bireuen. Nadwa: Jurnal Pendidikan Islam, 2 (1), 89-116. DOI: 10.21580/nw.2018.12.1.2232

Saiful, A. (2016). Nilai-Nilai Pendidikan Akhlak dalam Kitab Khulasoh Nurul Yaqin Karya Muhammad Khudari Bek. Salatiga: Institut Agama Islam Negeri Salatiga.

Suryosubroto. (2002). Proses Belajar Mengajar di Sekolah. Jakarta: Rineka Cipta.

Zainudin, M, Ali, N., \& Mujtahid (Eds.). (2009). Pendidikan Islam dari Paradigma klasik Hingga Kontemporer. Malang: UIN-Malang Press.

Zubaedi. (2012). Desain Pendidikan Karakter: Konsep dan Aplikasinya dalam Lembaga Pendidikan. Jakarta: Kencana 